\title{
Investigations of the temperature distribution in the exhaust system of an aircraft piston engine
}

Ultralight aviation is based on piston engines requiring both performance and reliability. An important aspect is also the requirements for the installation of such an engine on an airframe, especially its heat emission. This is firstly because of the need to ensure proper engine cooling and secondly because composite elements of the airframe skin are not exposed to excessive overheating. For this purpose, bench tests of the temperature distribution of the exhaust system of ROTAX 912 engine were carried out. Measurements were taken at 6 points of the exhaust system, where the temperature of the exhaust gases and exhaust pipes were measured. The tests covered a wide range of engine operation. The paper presents the temperature distribution at selected points in relation to the engine speed and load.

Key words: aircraft engine, exhaust system, temperature distribution

\section{Introduction}

Ultralight aviation is one of the fastest growing fields of aviation industry. According to reports describing this market $[6,8]$, there are currently 50,000 ultralight aircraft in use in Europe and about $5.5 \%$ of them are added every year. This trend has been maintained for a period of 10 years [6]. According to the data [6], most of these aircraft (over 95\%) are powered by piston engines. Most of the European market is occupied by one manufacturer: ROTAX. Its engines are reliable and have a very good powerto-weight ratio. The disadvantage of these motors, however, is the low power of the electric generator.

Current aviation regulations [7] require aircraft manufacturers to install equipment that needs electrical power supply. These include: radio, transponder, contour lighting, stroboscopic lighting and avionics. In addition, very often the components related to easier use are installed: satellite navigation, lighting and heating of the cabin, charging external devices (e.g. mobile phones), etc. This results in a lack of energy. According to the authors [1, 2, 4] in some operating conditions the amount of electric energy consumed by on-board devices exceeds the amount of energy produced by the generator. This is contrary to the applicable aviation regulations [7].

It is therefore necessary to equip aircraft with additional sources of electrical energy. These may be additional batteries [2] or alternators driven by the motor shaft [6]. Another approach is the use of independent generator systems. The generators used are independent generators based on additional internal combustion engines [5] or thermogenerators [3]. The last proposal seems to be very promising due to the use of waste energy from the exhaust gas from the primary source of propulsion.

However, in developing a thermogenerator it is necessary to know the amount of available energy and the temperature of the medium interacting with the thermogenerator element. This temperature must not exceed the limits resulting from the materials used for this part.

This work is the initial stage of the development of a thermogenerator compatible with the ROTAX 912 en- gine. Its aim is to determine the temperature range of the exhaust system and the exhaust gases themselves in the whole range of engine operation.

\section{Research description}

\subsection{Research objects}

The object of the research is a ROTAX 912 ULS piston engine. The engine is a 4 cylinder 4 stroke reciprocating piston engine (boxer) - Fig. 1. The engine is cooled by air (cylinders) and coolant (cylinder heads). It is equipped with a dry oil sump system with an additional oil tank. The engine is integrated with the main reducer which reduces the rotational speed to the requirements of the propeller. The tested engine was equipped with authored fuel system - a sequential multi-point fuel injection system into the intake manifold. Engine parameters are described in Table 1.

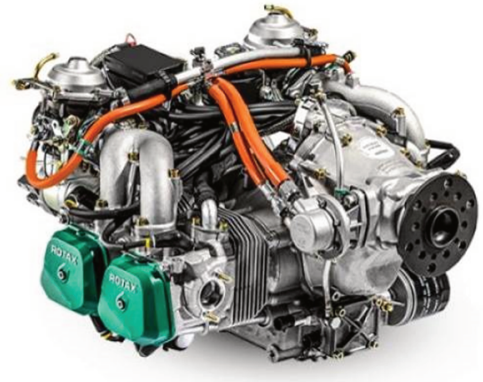

Fig. 1. ROTAX 912 ULS Engine

Table 1 Engine Parameters [2]

\begin{tabular}{|l|c|}
\hline Engine configuration & Flat engine (boxer) \\
\hline Cylinder number & 4 \\
\hline Displacement & $1352 \mathrm{~cm}^{3}$ \\
\hline Maximal power & $\begin{array}{c}73.5 \mathrm{~kW}(100 \mathrm{HP}) \text { at } 5800 \mathrm{RPM} \\
- \text { limited to } 5 \text { minutes }\end{array}$ \\
\hline Continuous power & $69 \mathrm{~kW}(93 \mathrm{HP})$ at $5500 \mathrm{RPM}$ \\
\hline Maximal torque & $128 \mathrm{Nm}$ at $5100 \mathrm{RPM}$ \\
\hline Weight & $56.6 \mathrm{~kg}$ \\
\hline Gearbox ratio & 2.43 \\
\hline Bore & $84 \mathrm{~mm}$ \\
\hline Stroke & $61 \mathrm{~mm}$ \\
\hline Compression ratio & $10.8: 1$ \\
\hline Fuel & RON95 \\
\hline
\end{tabular}




\subsection{Test stand}

The tests were carried out on a test stand located in the Centre for Innovation and Advanced Technologies of the Lublin University of Technology - Fig. 2. The dynamometer stand is made up of:

- Electro-mechanical brake: EMX - 200/6000 manufactured by Elektromex Centrum, with braking power up to $200 \mathrm{~kW}$ at the rotational speed up to $6000 \mathrm{rpm}$;

- Control system of the dynamometer: ATMX 2000 manufactured by ODIUT Automex SP. z o.o.;

- Gravimetric fuel meter with fuel conditioning: ATMX 2400 manufactured by ODIUT Automex SP. z o.o. has a fuel temperature and pressure control system.

- The system of oil heat exchangers, engine cooling water and brake cooling.

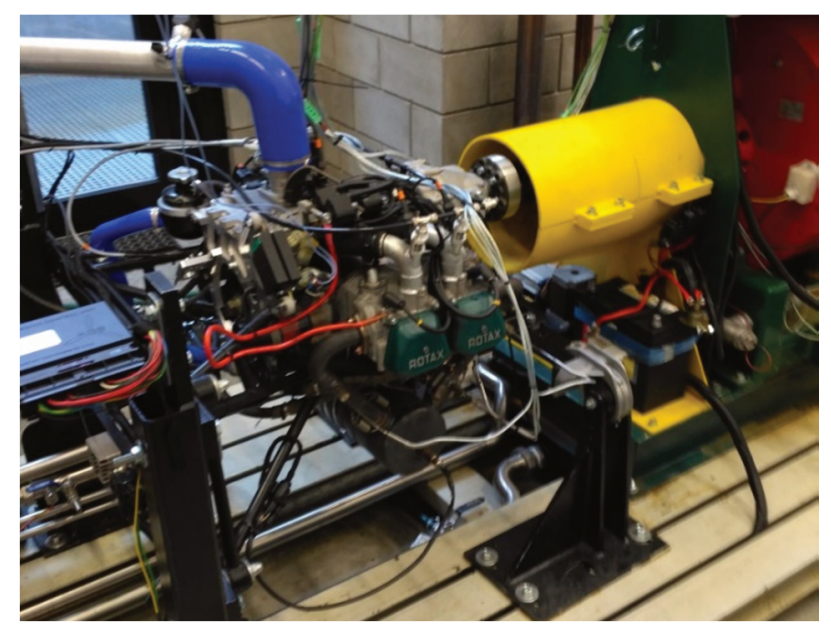

Fig. 2. Test stand

Exhaust system temperature measurements were carried out on a standard ROTAX engine exhaust system. Temperature sensors were placed in the exhaust system at specific distances from cylinders - 30, 180, 400, 600 and $1000 \mathrm{~mm}$, both inside the system (gas temperature measurement) and outside (wall temperature measurement). The location of measurement points is shown in Fig. 3.

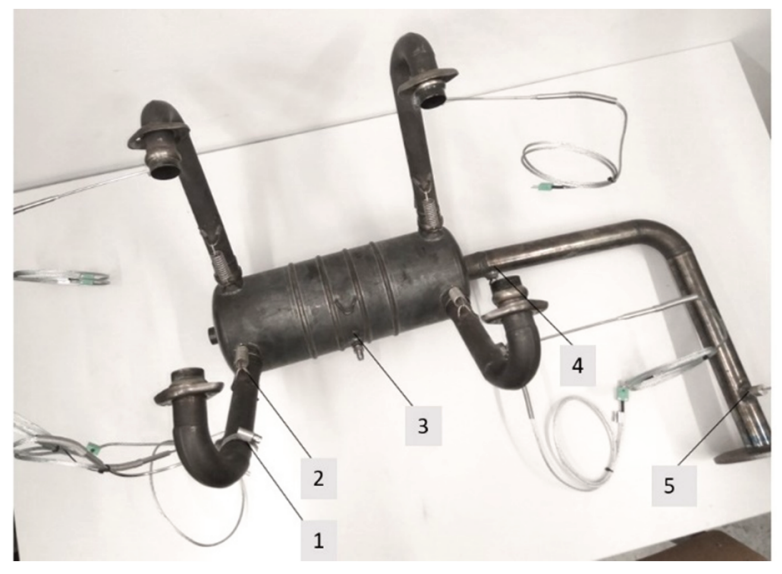

Fig. 3. Exhaust system of ROTAX 912 ULS engine

Thermocouples type $\mathrm{K}(\mathrm{NiCr}-\mathrm{NiAl})$ manufactured by Czaki Thermo - Product were used during the research. Sensors TP-204K-1b-150-1 were used to measure the tem- perature of exhaust gases and sensors TP-203K-1b-150-1 to measure the temperature of exhaust system elements, the insulation of the cable was a glass fibre with a screen. The location of the sensors is shown in Fig. 4.

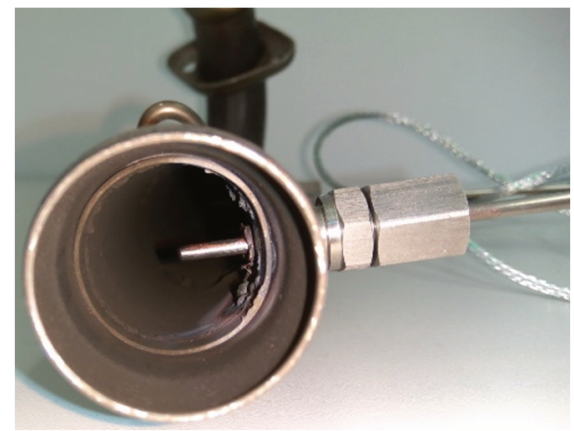

Fig. 4. Temperature sensor mounting

Measurements of signals from sensors were made with the use of NI 9213 measuring devices produced by National Instruments embedded in a four-socket, Ethernet and USB transmission. The DAQ module processes signals from the measuring card and sends them via digital transmission to the computer. To analyze the results, the program was developed in an National Instruments - LabVIEW - Fig. 5.

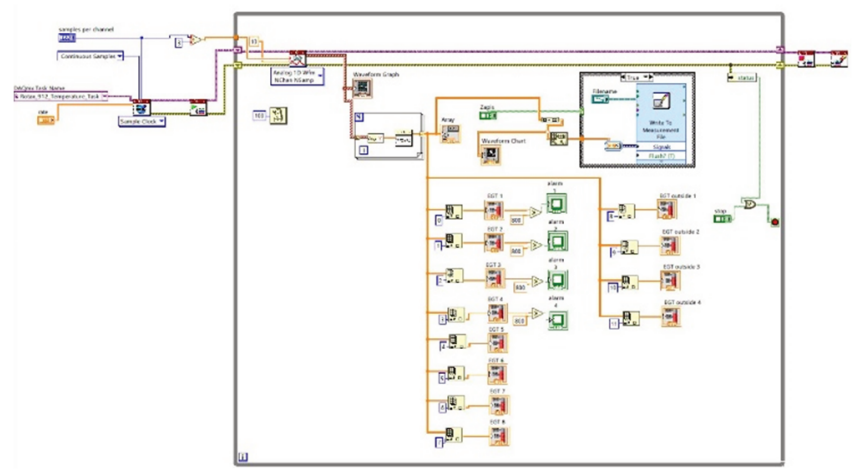

Fig. 5. Analyze program layout

\subsection{Scope of research}

The aim of the tests was to analyze the distribution of exhaust gas temperature and the external temperature of the exhaust system in a wide range of engine operation on a test stand. The analysis covered both the distribution of temperatures at particular operating points and their difference in charges from the distance from the cylinder.

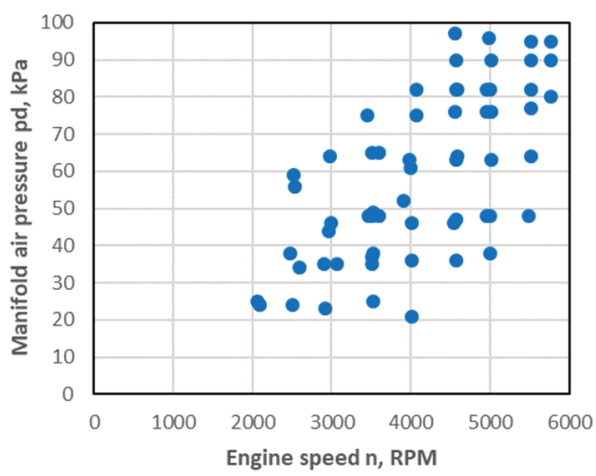

Fig. 6. Engine operational point use in the research 
The scope of work included measurements of temperatures in points described in chapter 2.2 in steady state of engine operation at test points determined by the rotational speed and manifold air pressure. The tests were carried out in 61 points (Fig. 6) covering the range of rotational speed 2060 - 5770 RPM, and the manifold air pressure $21-97$ $\mathrm{kPa}$. The tests were carried out in steady state of engine operation.

10 temperature signals were recorded in the exhaust system at specific distances from the cylinders - 30, 180, 400, 600 and $1000 \mathrm{~mm}$, both inside the system (gas temperature measurement) and outside (wall temperature measurement).

\section{Results}

The following figures show the results of temperature distribution tests at selected points of the exhaust system. The results are presented as a function of engine speed and manifold air pressure. The measured values and approximation of the second degree polynomial surface were presented.

Figure 7 shows the distribution of exhaust gas temperatures at the first measuring point $30 \mathrm{~mm}$ from the cylinder head number 1 . The lowest recorded temperature is $536^{\circ} \mathrm{C}$ and occurs at idling of this engine: rotational speed 2060 RPM and manifold air pressure $25 \mathrm{kPa}$. An increase in rotational speed and manifold pressure leads to an increase in exhaust gas temperatures. At full engine power (5770 RPM and pressure $98 \mathrm{kPa}$ ) the temperature reaches $762^{\circ} \mathrm{C}$.

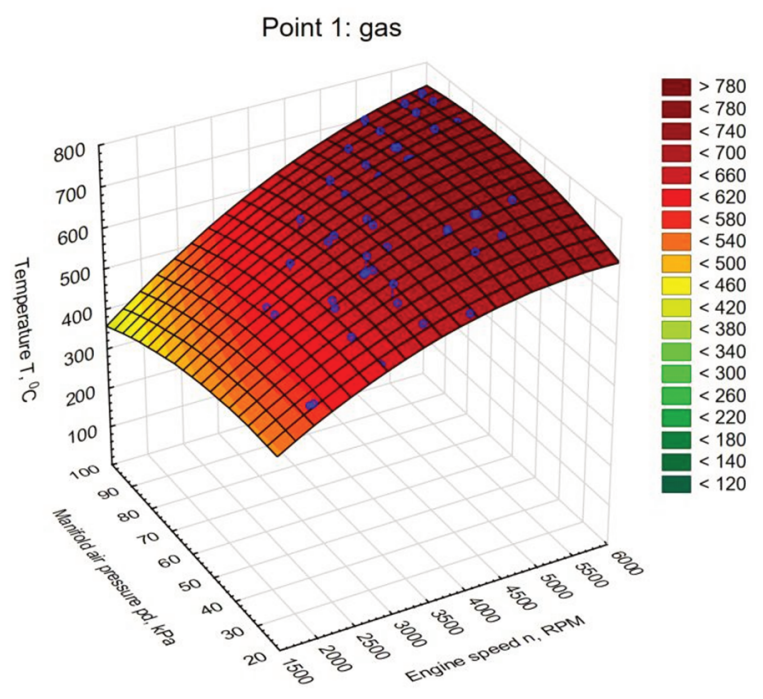

Fig. 7. Exhaust gas temperature at point 1 as a function of rotational speed and manifold air pressure

The temperature of the exhaust system walls at this point also increases with an increase in engine speed and manifold air pressure - Fig. 8. For idling, this temperature is $423^{\circ} \mathrm{C}$ and for maximum power $661^{\circ} \mathrm{C}$.

Similar relationships are also visible for the second measuring point $180 \mathrm{~mm}$ from the cylinder head $1-$ Figs 9 and 10 . The lowest temperatures recorded are at idle and are $384^{\circ} \mathrm{C}$ for gas and $291^{\circ} \mathrm{C}$ for the exhaust wall, respectively. They are approximately $130^{\circ} \mathrm{C}$ lower than at the previous measuring point. The highest recorded temperature is $764^{\circ} \mathrm{C}$ for gas and $603^{\circ} \mathrm{C}$ for the wall, respectively. It is noticeable that the maximum gas temperature is practi- cally identical to the temperature at point 1 and the wall temperature is only $58^{\circ} \mathrm{C}$ cooler.

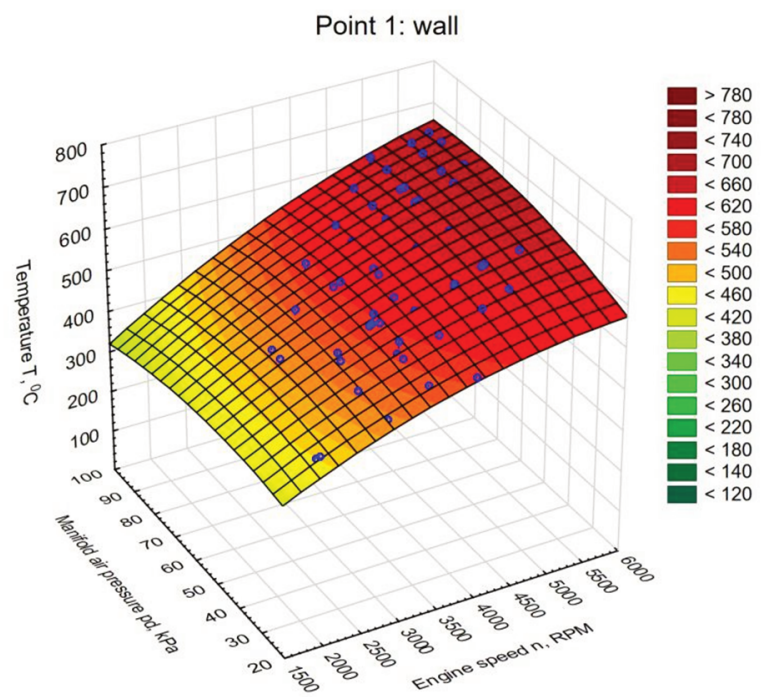

Fig. 8. Exhaust wall temperature at point 1 as a function of rotational speed and manifold air pressure

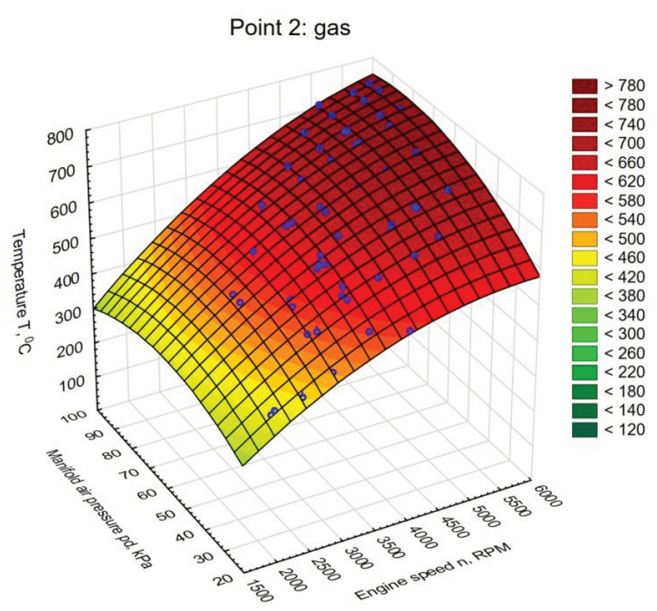

Fig. 9. Exhaust gas temperature at point 2 as a function of rotational speed and manifold air pressure

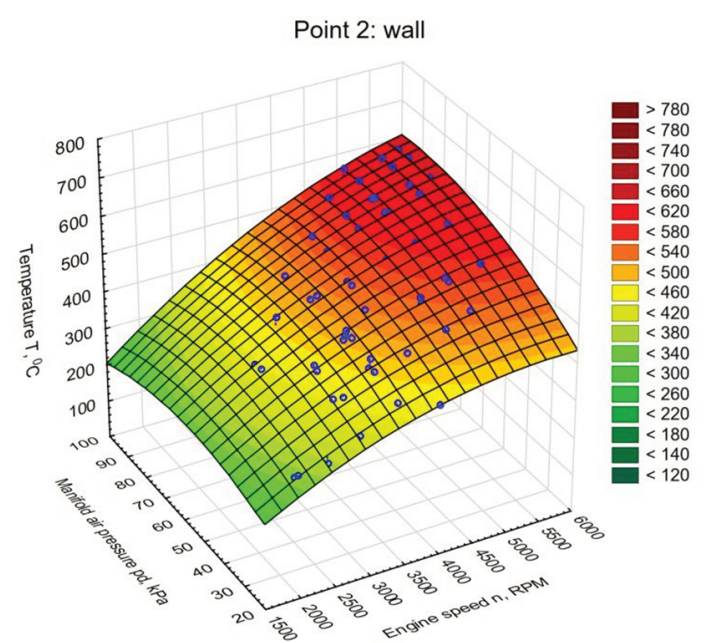

Fig. 10. Exhaust wall temperature at point 2 as a function of rotational speed and manifold air pressure 
The third measuring point is located in the silencer, which is a central exhaust manifold and is about $400 \mathrm{~mm}$ away from the cylinders. Here too, the rotational speed and manifold air pressure directly affect the temperature increase - Figs 11 and 12. The lowest recorded temperature also occurs at idle and is $306^{\circ} \mathrm{C}$ for gas and $207^{\circ} \mathrm{C}$ for the exhaust manifold wall, respectively. This represents a decrease of about $80^{\circ} \mathrm{C}$ compared to the previous point. The maximum temperature (occurring at maximum engine load) was $750^{\circ} \mathrm{C}$ for gas and $589^{\circ} \mathrm{C}$ for exhaust manifold walls, respectively. It is only $14^{\circ} \mathrm{C}$ lower than the values obtained in the previous point.

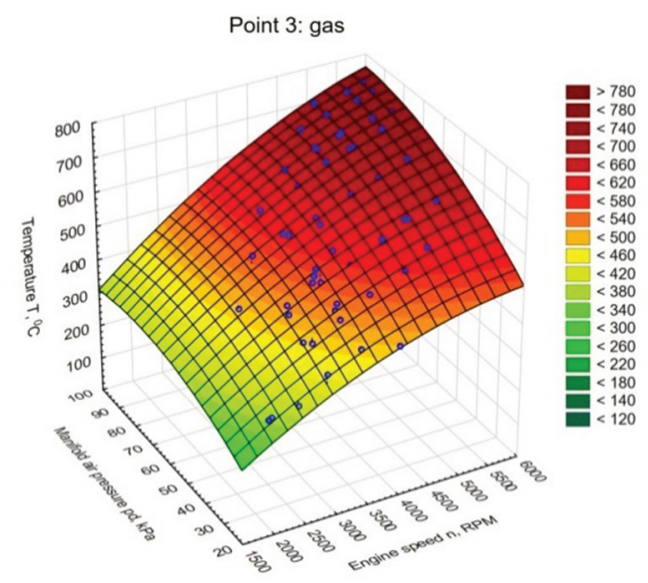

Fig. 11. Exhaust gas temperature at point 3 as a function of rotational speed and manifold air pressure

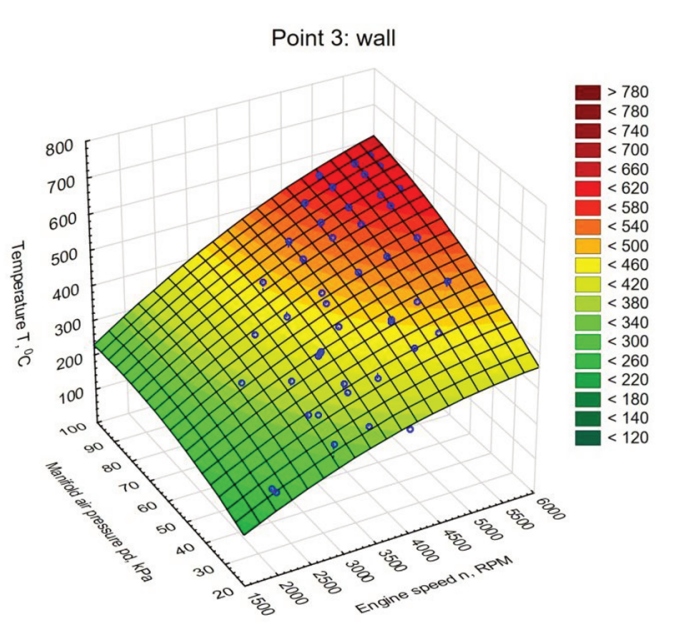

Fig. 12. Exhaust wall temperature at point 3 as a function of rotational speed and manifold air pressure

Another measuring point is located at the silencer exit $600 \mathrm{~mm}$ from cylinder head no. 1. At this point, as in the previous ones, an increase in rotational speed and manifold pressure leads to an increase in temperature - Figs 13 and 14. The lowest temperature also occurs at idle and is $316^{\circ} \mathrm{C}$ and $231^{\circ} \mathrm{C}$ for the manifold walls, respectively. The highest recorded temperatures are $752^{\circ} \mathrm{C}$ for gas and $648^{\circ} \mathrm{C}$ for the manifold wall, respectively. These temperatures are about $10^{\circ} \mathrm{C}$ higher than in the previous point for gas and up to $60^{\circ} \mathrm{C}$ for the wall. This is due to two facts: Firstly, the gases are compressed here again by the geometry of the manifold, which increases their temperature and the heat dissipation area is much smaller than at point 3 .

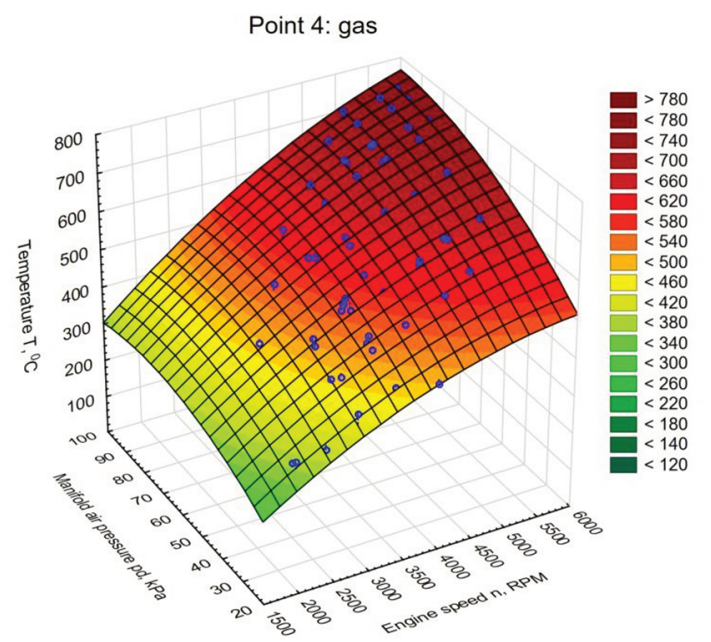

Fig. 13. Exhaust gas temperature at point 4 as a function of rotational speed and manifold air pressure

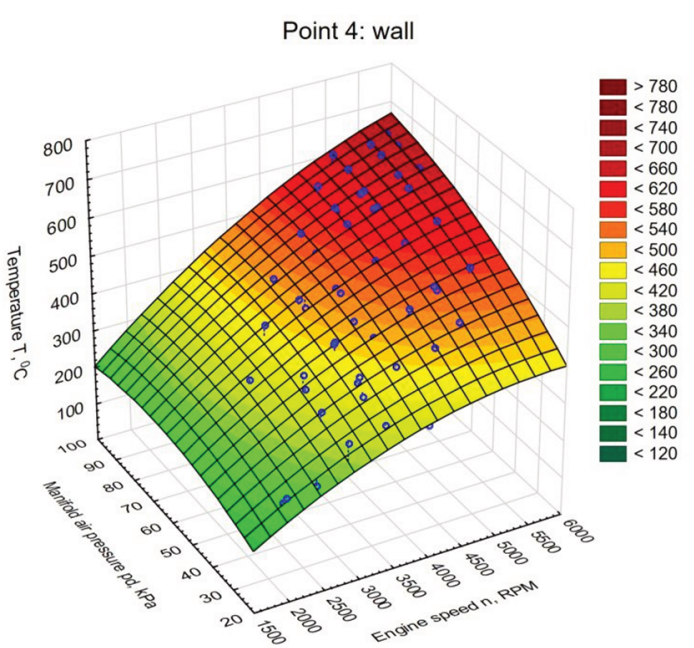

Fig. 14. Exhaust wall temperature at point 4 as a function of rotational speed and manifold air pressure

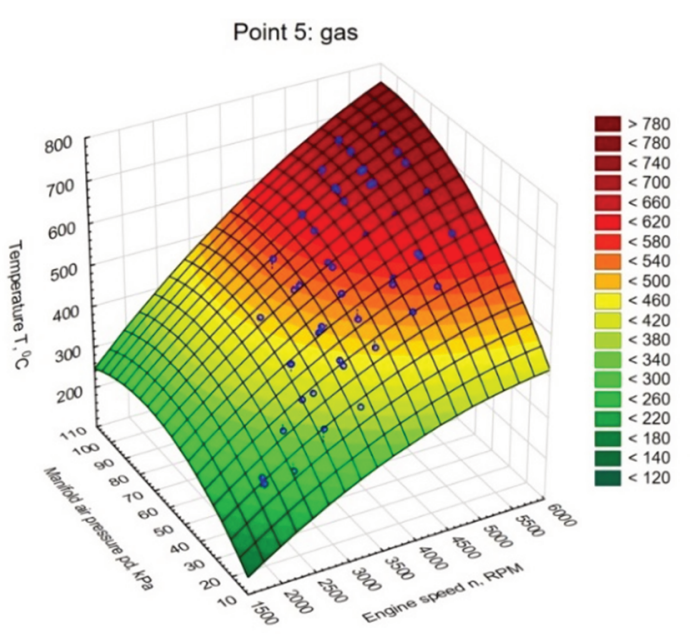

Fig. 15. Exhaust gas temperature at point 5 as a function of rotational speed and manifold air pressure 
The last measuring point is $1000 \mathrm{~mm}$ from the cylinder head 1 practically at the end of the engine outlet manifold. Again, an increase in speed and manifold air pressure causes an increase in temperature - Figs 15 and 16. The lowest recorded temperature occurs when the engine is idle and is $278^{\circ} \mathrm{C}$ for gas and $170^{\circ} \mathrm{C}$ for the manifold wall, respectively. The highest occurs for the highest engine load $\mathrm{I}$ is $731^{\circ} \mathrm{C}$ for gas and $637^{\circ} \mathrm{C}$ for the manifold wall, respectively. Therefore, the temperature of both gases and the wall temperature drops again compared to the previous point.

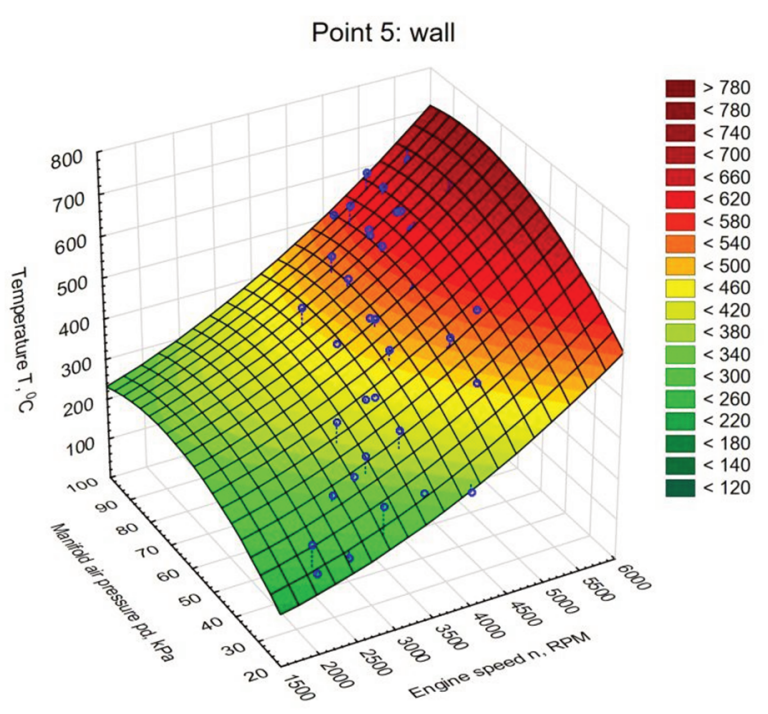

Fig. 16. Exhaust wall temperature at point 5 as a function of rotational speed and manifold air pressure

Temperature differences between the gas and the exhaust manifold wall were also analyzed. For the first measuring point, Fig. 17, it is visible that the increase in speed leads to an increase of the difference and the increase in manifold air pressure decrease of this difference. The smallest difference of $71^{\circ} \mathrm{C}$ was recorded for the rotational speed of $4555 \mathrm{rpm}$ and manifold air pressure of $21 \mathrm{kPa}$. The largest one, i.e. $14^{\circ} \mathrm{C}$, was recorded at $4015 \mathrm{rpm}$ and 21 $\mathrm{kPa}$.

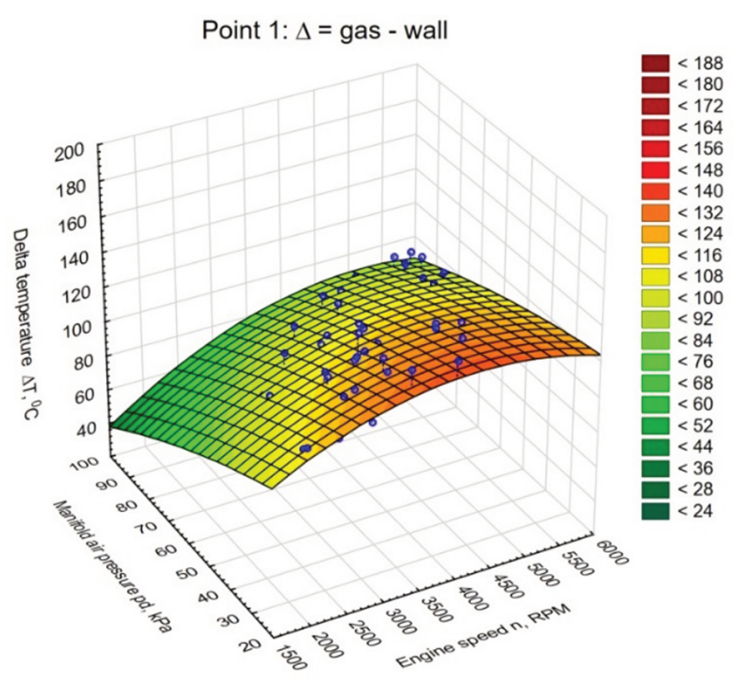

Fig. 17. Temperature difference between exhaust gas and exhaust manifold wall at point 1 as a function of engine speed and manifold air pressure
A different relationship was observed for point 2 - Fig. 19. At this point, the increase in engine speed and manifold air pressure results in an increase in the difference in temperature analyzed. The lowest value equal to $93^{\circ} \mathrm{C}$ was recorded for idling and the highest value of $161^{\circ} \mathrm{C}$ for maximum power.

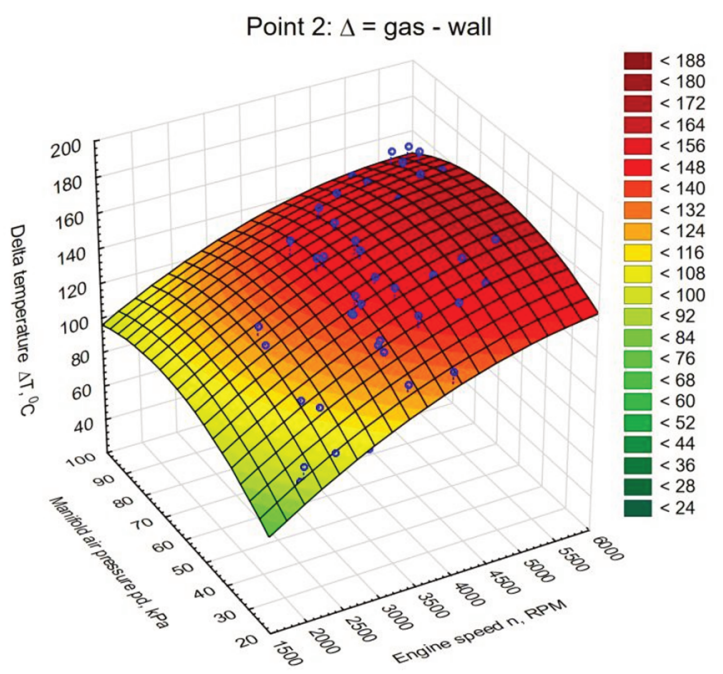

Fig. 19. Temperature difference between exhaust gas and exhaust manifold wall at point 2 as a function of engine speed and manifold air pressure

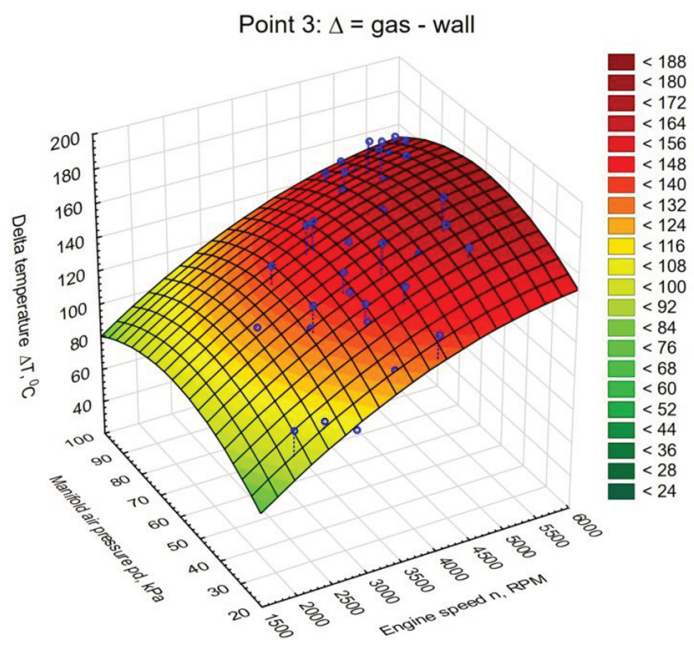

Fig. 20. Temperature difference between exhaust gas and exhaust manifold wall at point 3 as a function of engine speed and manifold air pressure

A similar relationship can be seen at point 3 - Fig. 20 . The lowest value of $92^{\circ} \mathrm{C}$ was recorded for idling and the highest value of $186^{\circ} \mathrm{C}$ for maximum power.

Also at point 4 , the dependence of the temperature difference on the engine speed and manifold air pressure is similar to the previous points - Fig. 20. The lowest value of $56^{\circ} \mathrm{C}$ was recorded for idling and the highest value of $118^{\circ} \mathrm{C}$ for maximum power. However, there is a significant flattening of the analysed difference at higher rotational speeds and intake manifold pressures. In the speed range above $4000 \mathrm{rpm}$ and pressure above $60 \mathrm{kPa}$, the temperature difference is almost unchanged. 


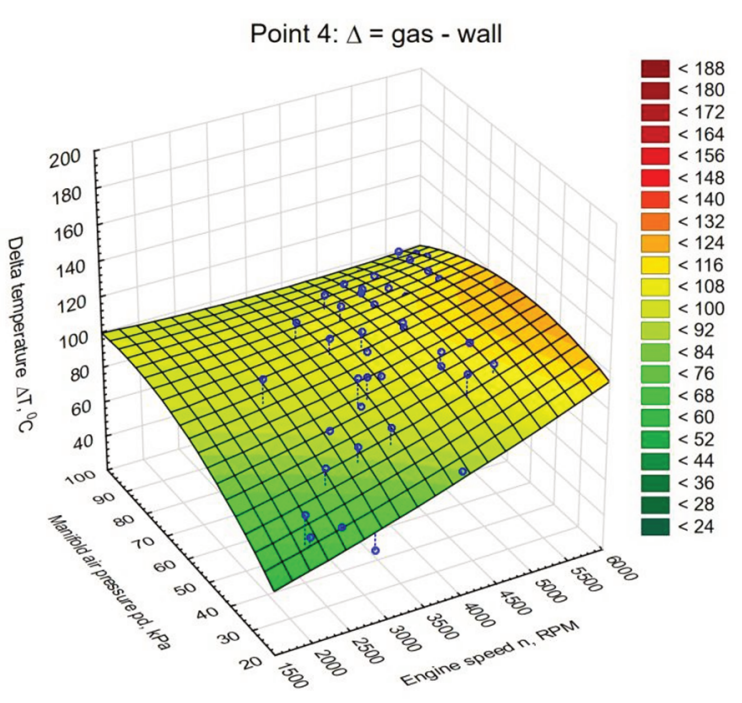

Fig. 21. Temperature difference between exhaust gas and exhaust manifold wall at point 4 as a function of engine speed and manifold air pressure

The smallest changes, i.e. the greatest stability of the temperature difference between the gas and the walls of the exhaust manifold, are shown in point 5 - Fig. 22. The approximated value of the differences oscillates around 80$100^{\circ} \mathrm{C}$ and the visible deviation of measurement points from the approximated surface results from a random sequence of measurements.

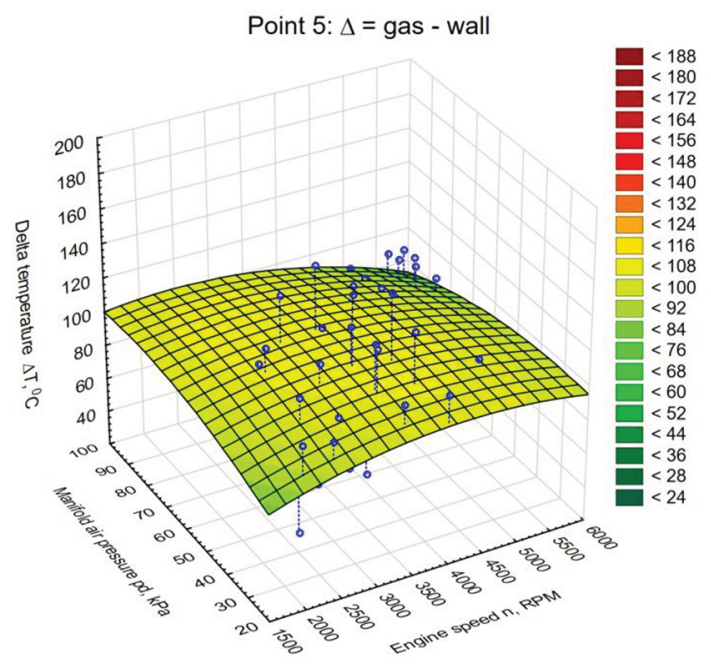

Fig. 22. Temperature difference between exhaust gas and exhaust manifold wall at point 5 as a function of engine speed and manifold air pressure

\section{Conclusions}

Conducted tests of temperature distribution along the exhaust manifold allowed the following conclusions to be made: The temperature distribution along the outlet manifold is the result of the study:

1. The temperature of the exhaust gases and the temperature of the exhaust manifold walls is proportional to the engine speed and the load degree expressed by the manifold air pressure. The operating conditions have a significant influence on the temperature level. At a point $30 \mathrm{~mm}$ from cylinder head no. 1, the minimum exhaust temperature was $536^{\circ} \mathrm{C}$ and the maximum temperature was $762^{\circ} \mathrm{C}$.

2. The temperature of the exhaust gas and the temperature of the exhaust manifold walls decreases with the distance from the cylinder head. An exception to this rule is the exhaust outlet from the silencer to the exhaust pipe, where the temperature rises relative to the silencer temperature as a result of re-compression.

3. The maximum exhaust gas temperature does not decrease significantly with length. It is $762^{\circ} \mathrm{C}$ at point 1 and $731^{\circ} \mathrm{C}$ at point $5(1000 \mathrm{~mm}$ from cylinder head no. 1). A similar gradient is visible at the temperature of the exhaust manifold wall: $661^{\circ} \mathrm{C}$ at point 1 and $637^{\circ} \mathrm{C}$ at point 5 , respectively.

4. The lowest average temperatures of exhaust gas and manifold walls are at point 3 - silencer. This is due to the temperature drop due to the expansion of the exhaust gases.

5. At all measuring points, the temperature difference between the exhaust gas and the walls remains within a similar range. The average value is about $120^{\circ} \mathrm{C}$ and results from the thermal conductivity of the exhaust manifold material and the degree of heat transfer to the surroundings.

To summarize, it can be stated that the engine exhaust manifold can be used as a heat source for the thermogenerator. Due to the level of maximum temperatures exceeding the limit values for thermocouples, it is not possible to install them directly on the manifold walls. It is therefore necessary to use heat-conducting elements that allow the temperature to be lowered to acceptable levels.

\section{Acknowledgements}

This work was financed from the core funds for statutory $R \& D$ activities by the Polish Ministry of Science and Higher Education. The authors gratefully acknowledge the support.

\section{Bibliography}

[1] CZARNIGOWSKI, J., SKIBA, K. Electric energy balance of the ROTAX 912 with fuel injection. Journal of KONES Powertrain and Transport. 2017, 24(1). DOI: 10.5604/ 01.3001.0010.2834.

[2] KANG, G.-W., HU, Y., LI, Y.-D., JIANG, W.-H. Parameters matching of ultralight electric aircraft propulsion system. Hangkong Dongli Xuebao/Journal of Aerospace Power. 2013, 28(12), 2641-2646. www.scopus.com/inward/record. uri?eid=2-s2.0-84891890860\&partnerID=40\&md5= b9e3dab95eb862a2441425fefd7848bc
[3] STOCKHOLM, J.G. Applications in thermoelectricity. Materials Today: Proceedings. 2018, 5(4), 1, 10257-10276, DOI:10.1016/j.matpr.2017.12.273.

[4] TOMAŽIČ, J., TOMAŽIČ, T., ŽEMVA, A. Battery-cell balancing in electric-powered ultralight aircraft [Napetostno izenačevanje akumulatorjev $\mathrm{v}$ ultralahkih letalih na električni pogon]. Elektrotehniski Vestnik/Electrotechnical Review. 2010, 77(4), 188-193, www.scopus.com/inward/record.uri?eid=2-s2.0-79551613076\&partnerID $=40 \& \mathrm{md} 5=$ 6d7e93c2b8b848245c2bde2a25aa311e 
[5] ZHU, Q., FORSYTH, A., TODD, R. Investigation of hybrid electric aircraft operation on battery degradation. 2018 IEEE International Conference on Electrical Systems for Aircraft, Railway, Ship Propulsion and Road Vehicles and International Transportation Electrification Conference. ESARSITEC 2018, art. 8607617, 2019. www.scopus.com/inward/ record.uri?eid $=2$-s2.0-85062082639\&doi $=10.1109 \% 2 \mathrm{fESA}$ RSITEC. $2018.8607617 \&$ partnerID $=40 \& \mathrm{md} 5=67 \mathrm{fc} 1 \mathrm{~d} 4 \mathrm{~b} 18 \mathrm{~d}$ 7bb37a139a17c9d0d0d7e
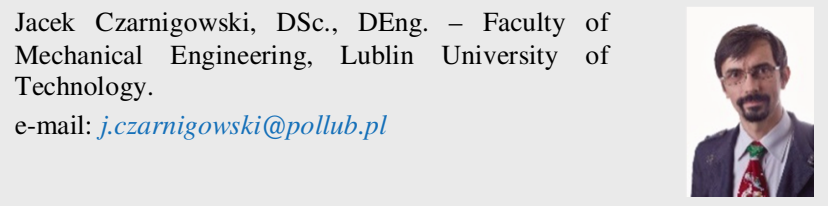

Kamil Bubeński, Eng. - Faculty of Mechanical Engineering, Lublin University of Technology.

e-mail: kamil.dubenski@pollub.edu.pl
[6] 2015 General Aviation Statistical Databook \& 2016 Industry Outlook General Aviation Manufacturers Association.

[7] European Aviation Safety Agency. Certification Specifications for Very Light Aeroplanes CS-VLA. ED Decision 2009/003/R.

[8] Light Aircraft Global Market Growth, CAGR, Trend Status and Forecast 2018- 2025. ReportHive 2018.

[9] Regulatory Options for the European Light Aircraft (ELA1) Phase 3 FINAL REPORT". november 2010 EASA.

Krzysztof Skiba, MEng. - Faculty of Mechanical Engineering, Lublin University of Technology.

e-mail: k.skiba@pollub.pl

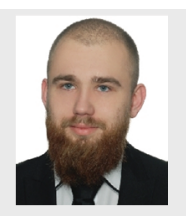

